\title{
Green Infrastructure of Post-USSR Cities for Prevention of Noise Pollution
}

\author{
Nadiya Maksymenko ${ }^{1}$, Sergiy Sonko ${ }^{2}$, Hanna Skryhan $^{3}$, Svitlana Burchenko ${ }^{1,4^{*}}$, and Anton Gladkiy ${ }^{1}$ \\ ${ }^{1}$ Department of Environmental Monitoring and Nature Use, Karazin Institute of Environmental Sciences, V. N. Karazin Kharkiv \\ National University, Svobody sq., 6, 61022, Kharkiv, Ukraine \\ ${ }^{2}$ Department of ecology and safety of vital functions, Uman National University of Horticulture, Instytutska str., 1, Uman, 20300, \\ Cherkasy region, Ukraine \\ ${ }^{3}$ Department of Road Construction, Belarusian-Russian University, pr. Mira, 43, 212000, Mogilev, Belarus \\ ${ }^{4}$ Ipris-Profil Ltd., Plytkova str., 12, Kharkiv, 61106, Ukraine
}

\begin{abstract}
The green infrastructure provides many different benefits for the environment and for human well-being. One of these benefits - protecting from noise pollution. The study of the deterioration of the ecological situation in cities is associated not only with the study of natural but also with physical environmental factors of natural and artificial origin. Increasingly, physical factors are defined as risk factors for the urban population and belong to the group of anthropogenic factors. Increased urbanization, mechanization of processes and the development of the transport network are intensifying influences for citizens. Territorial organization of the urban landscape in post-USSR cities, is quite complex and has signs of spontaneous formation, without protective function of green infrastructure from noise pollution. The aim of this research is to measure noise levels in Moskovsky district in Kharkiv, Ukraine. Kharkiv is a large industrial city and noise pollution is a considerable factor of influence on the environment. Based on these tasks, we have analyzed noise pollution in Moskovsky district in Kharkiv. Were identified 80 experimental points. Noise measurement was performed using an instrument "Digital Sound Level Meter". Was made the noise maps for working day and weekend in the mornings and in the evenings. For mapping was used QGIS instrument interpolation. The normal level of noise for this district is 60-70 according to the Ukrainian normative document. The WHO recommends the level of noise less than 20-30 decibels. According to this also was analyzed the change in the noise level in the zones of green spaces and was studied the objects of green infrastructure witch reduce noise in the cities.
\end{abstract}

\section{Introduction}

The level of noise is an important aspect of the environment and can reduce the quality of global ecosystems and human well-being. Sources of acoustic noise are different fluctuations in solid, liquid and gaseous environment. Noise pollution is no less dangerous than chemical pollution. Therefore, the creation a strategy for urban development, municipal development plan etc. it is necessary to take in account the possibility of reducing noise levels. One option for reduce the noise pollution is the development of green infrastructure in cities.

The definition of "green infrastructure" (GI) is provided by the European Commission - is a strategically planned network of natural and seminatural areas with other environmental features designed and managed to deliver a wide range of ecosystem services such as water purification, air quality, space for recreation, and climate mitigation and adaptation [1].

\footnotetext{
${ }^{1}$ Corresponding author: s.burchenko@karazin.ua
}

To reduce excessive noise, preserve acoustically effective areas of the city, provide conditions for recreation and human health, it is necessary to develop special measures and implement technologies that reduce noise.

Traditional ways to reduce noise are legislative, construction and planning, organizational, technical and technological, design, and preventive measures. For reducing noise in the cities is noise control measures evaluated: 1) speed reduction, 2) pavement replacement, 3) decreased flow of heavy vehicles, 4) and all the measures together [2].

The acoustic load is the effect on a person of noise, is a set of sounds of different frequency and intensity that occur due to natural and technical factors [3].

The acoustic load is a parameter of noise pollution and allows forming ecological requirements to the construction of industrial infrastructure of the environment taking into account comfortable and safe stay of the person in it. The acoustic load is manifested in an increase in noise levels above the natural background, where natural sounds which have a beneficial effect on humans, are increasingly 
overlapped by anthropogenic, intermittent, with significant power noises that adversely affect human health and state of biotic and non-biotic components within the urban ecosystem.

Numbers of studies investigated the impact of noise on the environment and human-health: with questionnaire of people $[4,5]$. The first step for regulation of level of noise is to compare experimental data (the measured noise) and legislative normative. Long-term studies of the effect of noise on human health allow us to speak about the positive role of green spaces $[6,7]$.

Territorial organization of the urban landscape in post-USSR cities, such as Kharkiv, is quite complex and has signs of spontaneous formation [8-10]. Green infrastructure had almost no protective function, with the exception of greenery in the sanitary protection zone of the plants. In our previous works [11] are investigated the shielding role of a green infrastructure in spreading of noise pollution.

Over the last decades, the level of acoustic pollution has been rapidly increasing due to the action of motor vehicles, along with the pollution of the environment with harmful toxic substances. This is due to the constant increase in the intensity of road traffic, the overall increase in engine power of cars, increasing speed and widening of roads. Noise is a form of physical pollution of the environment, and traffic noise is the excess of natural noise levels caused by the operation of engines, wheels, brakes and aerodynamic properties of the vehicle.

\section{Materials and methods}

\subsection{Study area}

As an experimental area, we have chosen the Moskovsky district in Kharkiv city. Moskovsky district occupies an area of $22,7 \mathrm{sq}$. $\mathrm{km}$, the population is more than 300 thousand people (fig. 1).

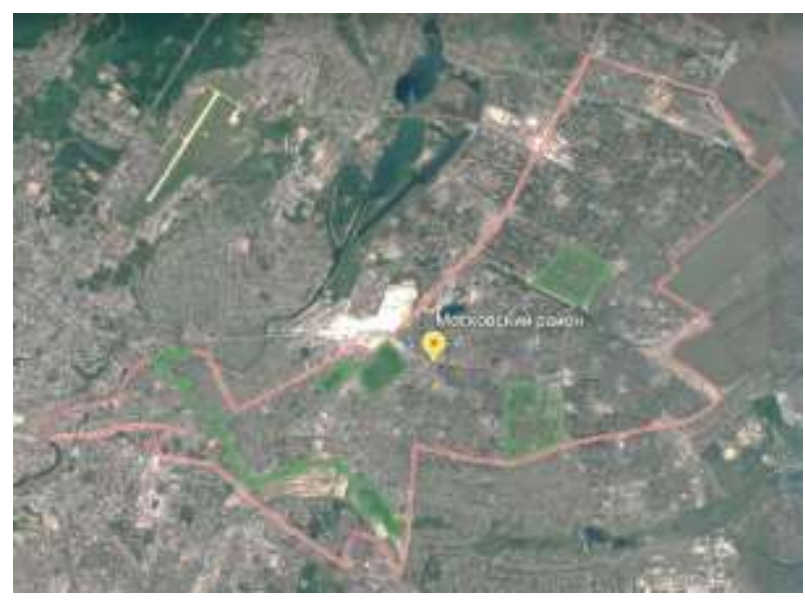

Fig. 1. Moskovsky district with the largest green zones

There are 35 large and medium-sized industrial enterprises in the district. There are also the main highways of the city. The territorial community of the city in the Moskovsky district has 1109 houses and 5064 private households. The total area of green zones is $4,62 \mathrm{sq} . \mathrm{km}$.

\subsection{Methods}

To assess a noise in different countries, the sound level in decibels is the total sound pressure level measured by a noise meter on the correction frequency curve A, which determines the generally accepted frequency response of noise perception by the human ear.

The main criteria for providing acoustic comfort in residential areas and surrounding areas are the normative equivalent noise levels of the residential area in accordance to government buildings normative (Ukraine) - GBN B 1.1-31:2013 [12]. Based on the reconnaissance survey of the territory of the district, key points were identified, at which were carried out noise measurements and calculation of the number of passing vehicles.

The acoustical performance of green living systems includes two different aspects: the outdoor noise absorption and the insulation of indoor environments from outside noise [13]. The main requirement for the range of key areas is the uniformity of placement, coverage of all functional areas, and the possibility of parallel measurement of noise near its source and behind the "sound screen" (inside the residential area).

The methods of measurements: on weekends and working days, in the morning, and in the afternoon.. Noise measurement was performed using an instrument "Digital Sound Level Meter". Were identified 80 experimental points (table 1). Repeated measurements - three times at each point every 10 munites The total volume of the experimental data - is 1440 measurements.

To illustrate how noise pollution is distributed in the area of Moskovsky district we used software QGIS, and an instrument of interpolation. The noise map gives a visual representation of the noise regime of the study area. The main sources are plotted on the map and indicate their equivalent noise levels of decibels.

\section{Results}

Normative noise level on the territory next to residential buildings:

- $\quad$ from 7 to 23 hours - 55 (decibels);

- from 23 to 7 hours - 45 (decibels).

According to [12] equivalent and maximum noise levels generated by road, rail, and air transport measure in $2 \mathrm{~m}$ from the structures of the first echelon of residential buildings and at a height of 1,2 meters (fig. 2 ). Buildings that protect from noise, hotels and dormitories facing on the main streets of city, railways, sources of aviation noise, are allowed to take 10 decibels above. 


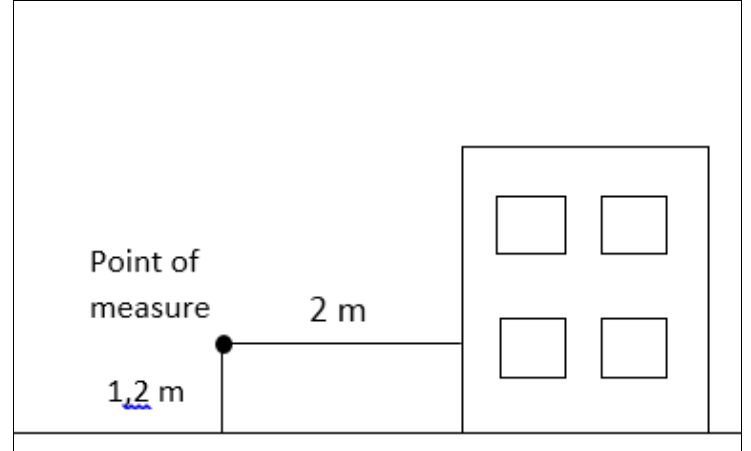

Fig. 2. Point location of noise measurement.

In addition, according to [12] in this area of urban development, is introduced an amendment $+5 \mathrm{~dB}$.

Thus, for this area, the standard noise level is:

- from 7 to 23 hours - 70 (decibels);

- from 23 to 7 hours - 60 (decibels).

The main source of external noise in this area are traffic flows consisting of cars and trucks, buses and trams. The initial noise parameter of the transport flow for various acoustic calculations is its noise characteristic.

As the noise characteristic is set an equivalent sound level generated by the flow at a distance of 7.5 $\mathrm{m}$ from the axis of the nearest lane and at a height of $1.5 \mathrm{~m}$ above the level of the roadway [14].

The initial data for calculating the noise characteristics of traffic flows are:
- traffic intensity during rush hours and the noisiest hour at night, units/hour;

- total share of freight and public transport in the flow, \%.

All points of measurement are present in figure 3 .

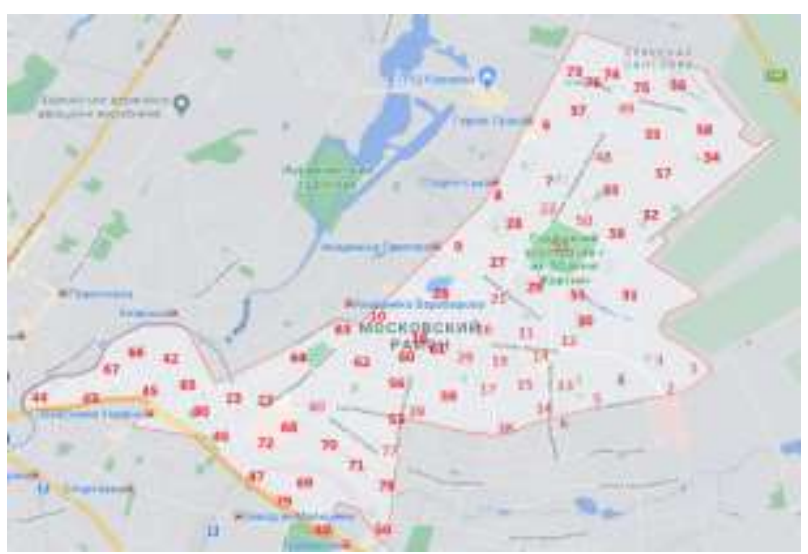

Fig. 3. The point of measurements at Moskovsky district

The requirement for the range of key areas is the uniformity of placement, coverage of all functional areas, and the possibility of parallel measurement of noise near its source and behind the "sound screen" was add. Common results of experimental data include 80 points of measurements (table 1). The mapping illustration of noise allocation is present in figures 4-7.

Table 1. The data of measurements of noise level in Moskovsky district.

\begin{tabular}{|c|c|c|c|c|c|c|c|c|c|}
\hline № & $\begin{array}{c}\text { Work day } \\
\text { (morning) }\end{array}$ & $\begin{array}{c}\text { Work day } \\
\text { (evening) }\end{array}$ & $\begin{array}{c}\text { Weekend } \\
\text { (morning) }\end{array}$ & $\begin{array}{c}\text { Weekend } \\
\text { (evening)d }\end{array}$ & $\mathbf{N}$ o & $\begin{array}{c}\text { Work day } \\
\text { (morning) }\end{array}$ & $\begin{array}{c}\text { Work day } \\
\text { (evening) dB }\end{array}$ & $\begin{array}{c}\text { Weekend } \\
\text { (morning) } \\
\text { dB }\end{array}$ & $\begin{array}{c}\text { Weekend } \\
\text { (evening)d } \\
\text { B }\end{array}$ \\
\hline $\mathbf{1}$ & 65,8 & 68,5 & 69,1 & 67,6 & $\mathbf{4 1}$ & 75,1 & 75,3 & 70,7 & 71,9 \\
\hline $\mathbf{2}$ & 68,9 & 70,6 & 72,5 & 72,6 & $\mathbf{4 2}$ & 79,4 & 80,3 & 77,4 & 76,7 \\
\hline $\mathbf{3}$ & 66,5 & 66,2 & 67,7 & 64,8 & $\mathbf{4 3}$ & 79,7 & 82,6 & 77,6 & 77,4 \\
\hline $\mathbf{4}$ & 66,0 & 64,9 & 65,0 & 61,8 & $\mathbf{4 4}$ & 79,2 & 81,2 & 77,8 & 80,6 \\
\hline $\mathbf{5}$ & 68,2 & 69,8 & 64,9 & 62,7 & $\mathbf{4 5}$ & 80,4 & 82,0 & 78,4 & 79,2 \\
\hline $\mathbf{6}$ & 73,0 & 72,9 & 74,4 & 76,0 & $\mathbf{4 6}$ & 83,1 & 81,2 & 76,7 & 77,6 \\
\hline $\mathbf{7}$ & 70,1 & 70,2 & 71,3 & 67,4 & $\mathbf{4 7}$ & 81,6 & 81,4 & 79,0 & 79,5 \\
\hline $\mathbf{8}$ & 71,2 & 71,8 & 72,6 & 67,0 & $\mathbf{4 8}$ & 81,2 & 81,2 & 81,6 & 82,6 \\
\hline $\mathbf{9}$ & 71,6 & 72,8 & 74,0 & 73,7 & $\mathbf{4 9}$ & 70,0 & 69,4 & 67,7 & 66,3 \\
\hline $\mathbf{1 0}$ & 76,0 & 77,6 & 75,1 & 73,3 & $\mathbf{5 0}$ & 77,1 & 75,9 & 72,6 & 70,5 \\
\hline $\mathbf{1 1}$ & 64,7 & 70,5 & 67,6 & 64,3 & $\mathbf{5 1}$ & 65,6 & 67,8 & 60,9 & 60,3 \\
\hline $\mathbf{1 2}$ & 65,7 & 70,6 & 70,5 & 65,5 & $\mathbf{5 2}$ & 57,2 & 55,0 & 51,9 & 52,6 \\
\hline $\mathbf{1 3}$ & 65,2 & 71,0 & 69,5 & 65,5 & $\mathbf{5 3}$ & 75,7 & 77,2 & 73,7 & 74,3 \\
\hline $\mathbf{1 4}$ & 74,6 & 71,2 & 72,5 & 73,2 & $\mathbf{5 4}$ & 57,6 & 55,4 & 52,3 & 51,9 \\
\hline $\mathbf{1 5}$ & 68,1 & 70,5 & 69,2 & 72,6 & $\mathbf{5 5}$ & 65,2 & 64,8 & 65,9 & 66,2 \\
\hline $\mathbf{1 6}$ & 69,2 & 68,2 & 70,8 & 70,5 & $\mathbf{5 6}$ & 73,3 & 74,8 & 73,0 & 73,6 \\
\hline $\mathbf{1 7}$ & 68,5 & 69,5 & 68,0 & 70,0 & $\mathbf{5 7}$ & 66,8 & 65,1 & 63,6 & 66,7 \\
\hline $\mathbf{1 8}$ & 70,6 & 72,8 & 72,5 & 71,6 & $\mathbf{5 8}$ & 66,5 & 62,0 & 65,1 & 64,1 \\
\hline $\mathbf{1 9}$ & 70,2 & 72,7 & 71,3 & 72,6 & $\mathbf{5 9}$ & 69,4 & 69,0 & 69,0 & 69,6 \\
\hline $\mathbf{2 0}$ & 66,4 & 66,2 & 68,9 & 69,8 & $\mathbf{6 0}$ & 70,3 & 68,0 & 71,2 & 72,6 \\
\hline $\mathbf{2 1}$ & 70,6 & 73,3 & 65,1 & 64,5 & $\mathbf{6 1}$ & 70,7 & 71,4 & 69,4 & 69,2 \\
\hline & & & & & & & & & \\
\hline
\end{tabular}




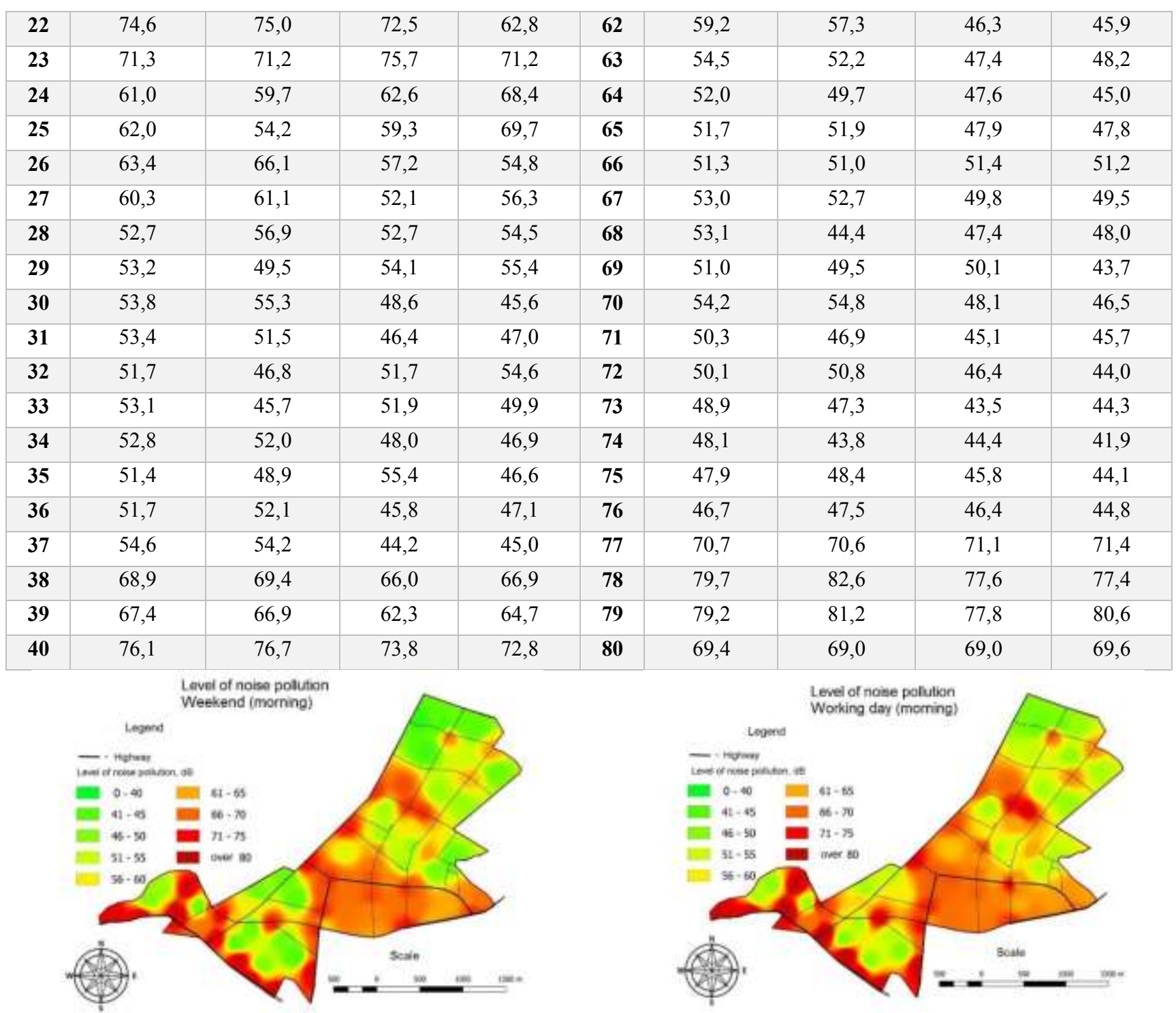

Fig. 4. Level of noise pollution at Moskovsky district (on weekend, morning).

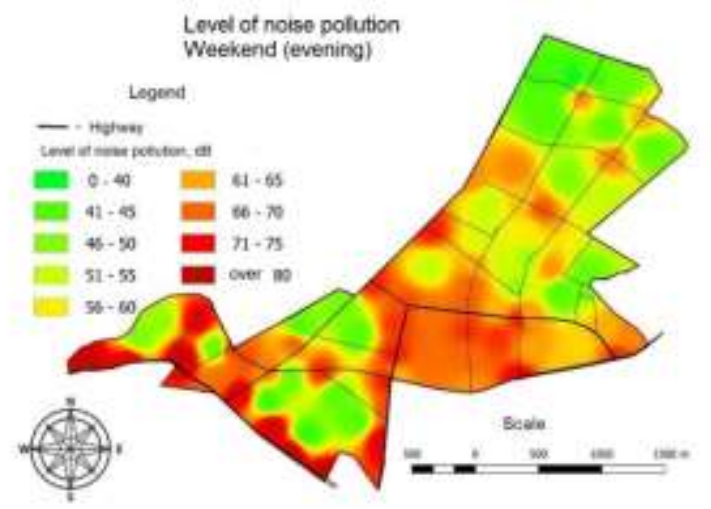

Fig. 5. Level of noise pollution at Moskovsky district (on weekend, evening).
Fig. 6. Level of noise pollution at Moskovsky district (on working day, morning).

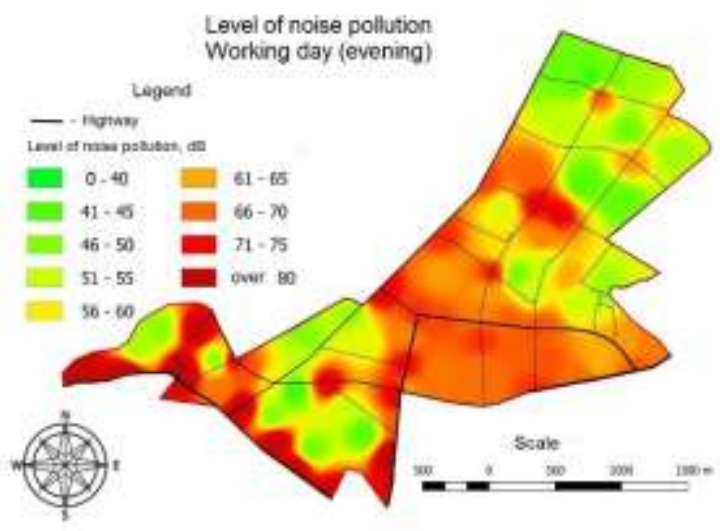

Fig. 7. Level of noise pollution at Moskovsky district (on working day, morning).

The highest noise levels in the Moscovsky region are observed in the south-western and central parts, both on weekends and on weekdays. This is because in these parts of the city there are industrial enterprises and large transport routes. 
At the same time in these parts of the area, there are no means of protection against noise. The building and small private houses are facing on the main highways are most affected by noise. At the same time, noise from vehicles is often pulsed and intermittent.

This disproportion is typical because during the USSR times, realization of the protective function of green zones was not laid down in urban planning and urban development. Thus, the existing green infrastructure of the area are an isolated islands, there are only inside a decrease of the anthropogenic noise load.

Noise with a level of 50-60 dB creates a significant load on the nervous system. Noise above $70 \mathrm{~dB}$ causes physiological effects; noise above $80 \mathrm{~dB}$ can lead to hearing loss.

Areas with low noise levels (up to $45 \mathrm{~dB}$ ) on weekdays and weekends are the greenest parts of the area.

In this case, the most interesting measurement is points next to green zones and inside there. The results of the measurement are present in table 2-4.

Table 2. Noise level next to Peremohy Park and inside

\begin{tabular}{|c|c|c|c|c|c|}
\hline № & $\begin{array}{c}\text { Work } \\
\text { day } \\
\text { (mor- } \\
\text { ning) }\end{array}$ & $\begin{array}{c}\text { Work } \\
\text { day } \\
\text { (eve- } \\
\text { ning) }\end{array}$ & $\begin{array}{c}\text { Weeke } \\
\text { nd } \\
\text { (mor- } \\
\text { ning) }\end{array}$ & $\begin{array}{c}\text { Weeke } \\
\text { nd } \\
\text { (eve- } \\
\text { ning) }\end{array}$ & $\begin{array}{c}\text { Stan- } \\
\text { dard } \\
\text { noise } \\
\text { level }\end{array}$ \\
\hline 13 & 65,2 & 71 & 69,5 & 65,5 & 70 \\
\hline 14 & 74,6 & 71,2 & 72,5 & 73,2 & 70 \\
\hline $\begin{array}{c}15 \\
\text { inside } \\
\text { park }\end{array}$ & 68,1 & 70,5 & 69,2 & 72,6 & 70 \\
\hline 19 & 70,2 & 72,7 & 71,3 & 72,6 & 70 \\
\hline 38 & 68,9 & 69,4 & 66 & 66,9 & 70 \\
\hline
\end{tabular}

Based on the data of the table and maps, we can see that in the green zone - Peremohy Park the standards are also exceeded. This is due to the fact that in addition to the highway there are also Heat power station № 3, Saltovsky bakery plant, and a tram line near the park. Thus, we can say that the absence of a park in this area would significantly increase the noise pollution of this area.

Table 3. Noise level next to private gardens " 50 th anniversary of October" and inside

\begin{tabular}{|c|c|c|c|c|c|}
\hline № & $\begin{array}{c}\text { Work } \\
\text { day } \\
\text { (mor- } \\
\text { ning), } \\
\text { дБ }\end{array}$ & $\begin{array}{c}\text { Work } \\
\text { day } \\
\text { (eve- } \\
\text { ning), } \\
\text { дБ }\end{array}$ & $\begin{array}{c}\text { Week- } \\
\text { end } \\
\text { (mor- } \\
\text { ning), } \\
\text { дБ }\end{array}$ & $\begin{array}{c}\text { Weeke } \\
\text { nd } \\
\text { (eve- } \\
\text { ning), } \\
\text { дБ }\end{array}$ & $\begin{array}{c}\text { Stan-dard } \\
\text { noise } \\
\text { level }\end{array}$ \\
\hline 22 & 74,6 & 75 & 72,5 & 62,8 & 70 \\
\hline 50 & 77,1 & 75,9 & 72,6 & 70,5 & 70 \\
\hline $\begin{array}{c}51 \\
\text { inside } \\
\text { gar- } \\
\text { den }\end{array}$ & 65,6 & 67,8 & 60,9 & 60,3 & 70 \\
\hline 55 & 65,2 & 64,8 & 65,9 & 66,2 & 70 \\
\hline 56 & 73,3 & 74,8 & 73 & 73,6 & 70 \\
\hline
\end{tabular}

Territories of private gardens "50th anniversary of October", and Nemyshlia river coastal zone have excesses over $70 \mathrm{~dB}$, and are observed mainly on weekdays in areas of highways.

Table 4. Noise level next to tree lines of road

\begin{tabular}{|c|c|c|c|c|}
\hline № & $\begin{array}{c}\text { Work day } \\
\text { (mor- } \\
\text { ning) }\end{array}$ & $\begin{array}{c}\text { Work } \\
\text { day } \\
\text { (eve- } \\
\text { ning) }\end{array}$ & $\begin{array}{c}\text { Weekend } \\
\text { (mor- } \\
\text { ning) }\end{array}$ & $\begin{array}{c}\text { Weekend } \\
\text { (eve-ning) }\end{array}$ \\
\hline 73 & 48,9 & 47,3 & 43,5 & 44,3 \\
\hline 74 & 48,1 & 43,8 & 44,4 & 41,9 \\
\hline 75 & 47,9 & 48,4 & 45,8 & 44,1 \\
\hline 76 & 46,7 & 47,5 & 46,4 & 44,8 \\
\hline
\end{tabular}

At these points, we see a decrease in the noise level due to the shielding of the forest. The average noise level in these points is $45,8 \mathrm{~dB}$. Thus, linear plantings in combination with polygonal and point objects of green infrastructure can significantly reduce the level of noise load on residents of urbanized areas.

\section{Discussion}

In the general case, the methods of reducing traffic noise can be classified into the following three areas: reducing noise at the source of its occurrence, including the decommissioning of vehicles and changing the routes of their movement; noise reduction on the way of its distribution; the use of sound protection in the perception of sound.

Landscaping is an effective measure to combat noise in cities. Trees that are planted close to each other, surrounded by dense bushes, significantly reduce man-made noise and improve the urban environment. Plants are endowed with a special noise-absorbing ability. Plantations of maple, poplar, and linden absorb from 10 to $20 \mathrm{~dB}$ of sound signals. A thick hedge can reduce highway noise by 10 times.

Urban green areas are an important factor of the negative influence of noise in large cities. The harmful effects of noise on human health are generally recognized and manifested in a wide range: from subjective irritations to pathological changes in the hearing organs, central nervous and cardiovascular systems.

Have been identified two types of impact of green infrastructure on noise propagation:

- reducing its intensity deep into the green zone (appropriate only to those who are inside of green areas);

- retention of dissemination of noise from roads to residential buildings by forest belts between them.

In general, when adjusting the territorial organization of urban landscapes, the noise protection role of green infrastructure should be taken into account.

Greening the building roofs and facades are an nature-based solution in sustainable architecture that 
can restore losses of a natural environment in dense urban areas.

Types of GI, which can reduce noise pollution, and which we suggest to reduce noise are:

- parks near to coastal river zone, other parks, squares and gardens,

- green wall on new buildings (mainly houses),

- green roofs on commercial and entertainment centers,

- rain gardens in parks, municipal and private buildings,

- green corridors (rivers and canals, including their banks, road and railway corridors, bicycle routes, footpaths),

- green parking of commercial and entertainment centers' parking, municipal parking .

These zones can be classified by their functional use and accessibility for the population according to legislative (fig. 8-9).

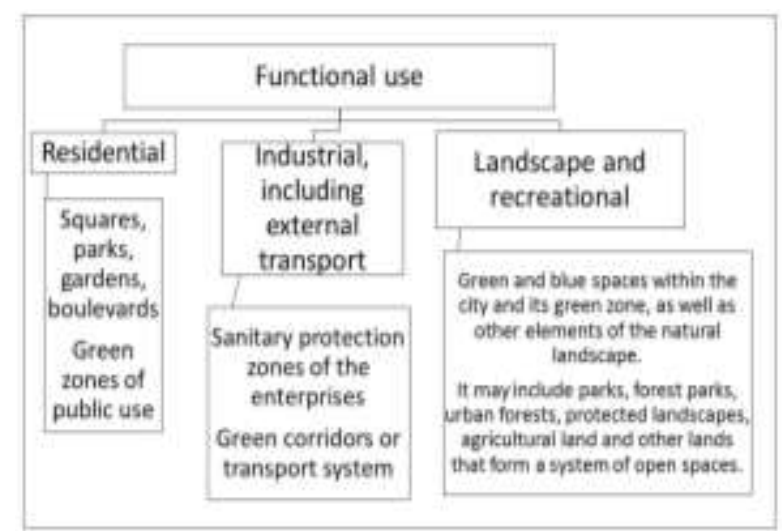

Fig. 8. Functional use of city's green areas

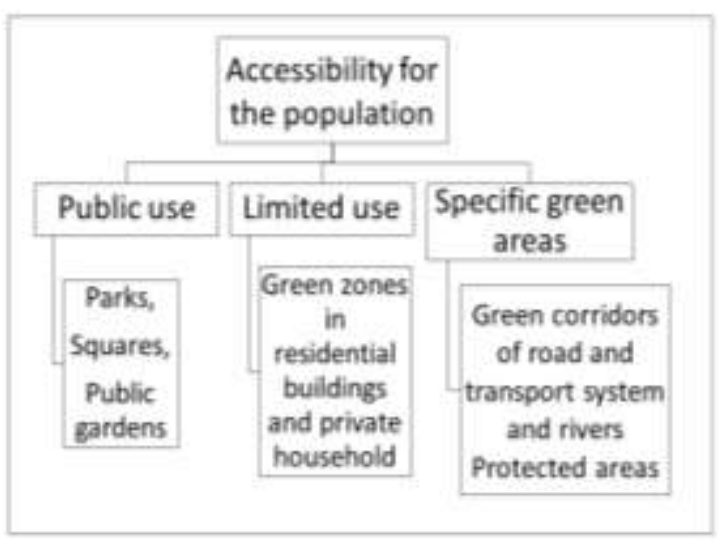

Fig 9. Accessibility of city's green areas for the population.

The important point is the absence of legislative and other normative documents of objects such as rain gardens, green roofs, walls and parking. Thus, such objects are mainly created on private territories and less often on urban land.

Parks, squares and gardens, regardless of their functional use and accessibility, occupy rather large areas, so the creation of new parks and polygonal objects may entail a conflict of interests of different land users.
Green roofs have the greatest potential for attenuating noise, and on certain roof shapes, may be able to reduce noise by up to 7,5 decibels. Also has other important environmental benefits, such as absorbing carbon dioxide, improving air quality, reducing the urban heat island effect, increasing urban biodiversity, and making streets and roofs look more attractive [5].

Green walls depending on the design and substrate can reduce as much as possible backward noise reflection and forward transmission from the wall [15].

Rain gardens is a garden of native shrubs, perennials, and flowers planted in a small depression, which is generally formed on a natural slope. It provide a temporarily hold and soak in rainwater runoff.

Green corridors in cities are linear zones of greenery. They are created not only along natural objects such as rivers but also along highways, railways etc. As shown in this research, it is linear plantings can reduce the noise level by about 20 decibels.

Green parking is a new way for cities to be environmentally more sustainable. They do not have a significant effect on the noise level in cities, but at the same time, they make the living space greener and not gray.

These areas and zones not only contribute to noise reduction but also provide ecosystem services such as:

- regulative services:

- regulation of surface runoff in the city - pollution control, groundwater recharging, flood control;

- air purification -trees or other plants also play an important role in regulating air quality by removing pollutants from the atmosphere;

- climate regulation - affect the climate both locally and globally. For example, on a local scale, changes in land cover (greening) can affect both temperature and precipitation;

- prevention of soil erosion - vegetation provides a vital regulatory service, preventing soil erosion;

- greenery creates a buffer against natural disasters, thus preventing possible damage, enhance the ability to adapt to the effects of climate change;

- carbon sequestration - regulate the global climate by storing and sequestering greenhouse gases. Trees and plants can remove carbon dioxide from the atmosphere and effectively lock it in their tissues.

- Cultural services:

- aesthetic values - many people find beauty or aesthetic value in various aspects of ecosystems, which is reflected in the support of parks and residential areas, the choice of places to live;

- social relations - affect the types of social relations that are established in a particular area;

- recreation and human well-being - people often choose where to spend their free time, based in part on the characteristics of natural or cultural landscapes in a particular area. Walking and playing sports in the green space is not only a good 
form of exercise, but also allows people to relax. The role that green space plays in maintaining mental and physical health is increasingly recognized.

- Provisioning services:

- impact on the overall biochemical cycle;

- support and impact on the global hydrological cycle.

- Supporting services:

- habitat for species.

The creation of green infrastructure objects such as green roofs, green walls, green corridors, rain gardens and green parking does not require large territories and capital investments. However, they can significantly reduce noise pollution in the area, regulate surface runoff, improve human well-being and provide ecosystem services, such as regulation of building temperatures, reduced urban heat-island effects, and increased urban biodiversity.

\section{References}

1. European Commission. Communication from the commission to the European Parliament, The council, the European economic and social committee and the committee of the regions. Brussels, 2013.

2. F. Bunn, P. H. Trombetta Zannin, Noise Control Eng. J. 63,1 (2015)

3. A. Tiasto, M. Kudymova, Young Sci, 10, p. 45-48 (2015) (in ukrainian)

4. J. Jablonska, Polish Political Science Review, 8(2), p. 101-109 (2020)

5. P.Ilić, Z. U. Rahman Farooqi, L. Stojanović, Indian Journal of Environmental Protection (2020) (to be published)

6. P. Morency, C. Plante, A.-S. Dubé, S. Goudreau1, C. Morency, P.-L. Bourbonnais, N. Eluru, L.-F. Tétreault1, M. Hatzopoulou,N. Chandra Iraganaboina, T. Bhowmik and A. Smargiassi, Int. J. of Environ. Res. Public Health, № 17(14), p. 50$61(2020)$

7. M. Foraster, I.C.Eze, D. Vienneaua,M. Brink, C. Cajochend, S. Caviezel, H. Héritier, E. Schaffner, C. Schindler, M. Wannere, J.-M. Wunderlif, M. Röösli, N. Probst-Hensch, Environment International, № 91, p. 341-349 (2016)

8. A. Klieshch, N. Maksymenko, J. of Geology, Geography and Geoecology, vol. 29 № 3, p. 539549 (2020)

9. A. A. Klieshch, Man and environment. Issues of neoecology, № 3-4 (24), p. 28-31 (2015)

10. A. A.Klieshch, Visnyk of V.N. Karazin Kharkiv National University series "Ecology" № 17, p. 6371 (2017)

11. GBN V.1.1-31:2013, Protection of territories, buildings and structures from noise, Kyiv,
Ministry of Regional Development, Construction and Housing of Ukraine, 2014, 48 p.

12. N. V. Maksymenko, I. I. Radionova, Visnyk of V.N. Karazin Kharkiv National University series "Ecology", №16, p. 113-118 (2017)

13. D. Dimitrijević, P. Živković, M. Dobrnjac, T. Latinović, Noise pollution reduction and control provided by green living systems in urban areas, in Scientific proceedings III international scientific-technical conference "Innovations", p. 124-127 (2017)

14. GOST 20444-2014, Noise. Traffic flows. Methods for determining the noise characteristic. [Effective from 2015-07-01], 15 p. (2014)

15. A. Emmanuel, B. Dubus, T. Leblois, Cretin Building and Environment, 187 (2021) 